\title{
Pengaruh Kepuasan Kerja, Keterlibatan Kerja dan Komitmen pada Organisasi Terhadap Turnover Intentions Di PT Sumber Purnama Sakti Mataram
}

\author{
Sulhan Hadi ${ }^{1)}$, Nurul Hidayati Indra Ningsih ${ }^{2)}$, Lalu Hendra Maniza ${ }^{3)}$ \\ Universitas Muhammadiyah Mataram \\ Email: indraningsih21@gmail.com
}

\begin{abstract}
This research is entitled The Influence of job satisfactions, job invlopment and organizational commitment on the turnover intentions at PT Sumber Purnama Sakti Mataram. The goals of this research are to identify the partial and simultant significances of the influence of job satisfactions, job invlopment and organizational commitment and to identify which of the variables has the most dominant influence. This research is causality by using sensus sampling method. The model of analysis applied in this research is multiple linier regression analysis where this model is used after testing classical assumptions, including multicollinearity, autocorrelation, and heteroscedasticity. The results of this research show, it can be identified that job satisfactions, job invlopment and organizational commitment have significant influences on the turnover intentions. with contribution equal $64 \%$. Analyzed partially, job satisfactions has the most dominant influence on turnover intentios.
\end{abstract}

Key Words: job satisfactions, job invlopment, organizational commitment turnover intentions, sumber purnama sakti

\section{PENDAHULUAN}

Dalam era globalisasi seperti sekarang ini, persaingan dalam dunia bisnis semakin hari semakin akan semakin ketat. Agar dapat lebih unggul dalam persaingan perusahaan harus memiliki kinerja yang terbaik serta mampu lebih kreatif dan inovatif dalam menjalankan usahnya sehingga suatu perusahaan akan lebih unggul dari pesaingpesaingnya. Untuk mencapai kinerja yang lebih baik perusahaan harus dapat memanfaatkan resources yang ada didalamnya termasuk memaksimalkan fungsi sumber daya manusia.

Sumber daya manusia merupakan aspek krusial yang akan menentukan keefektifan suatu organisasi ataupun perusahaan. Oleh karena itu perusahaan perlu untuk melakukan investasi dengan melakukan fungsi MSDM yakni melalui perekrutan, penyeleksian sampai mempertahankan sumber daya manusia. Dengan pelaksanaan fungsi MSDM yang baik maka perusahaan akan mendapatkan karyawan yang profesional dengan tingkat loyalitas yang tinggi kepada perusahaan.

Akan tetapi fenomena yang sering terjadi adalah ketika kinerja perusahaan telah berjalan dengan baik dapat dirusak baik langsung maupun tidak langsung oleh berbagai perilaku karyawan. Salah satu bentuk perilaku karyawan tersebut adalah adannya niat untuk keluar dari perusahaan (turnover intentions) yang dapat berujung pada keputusan karyawan untuk meninggalkan pekerjaannya. Niat untuk keluar (turnover intentions) dapat diartikan sebagai suatu pergerakan tenaga kerja untuk keluar dari organisasinya. Turnover dapat berbentuk pengunduran diri, perpindahan unit organisasi, pemberhentian atau kematian anggota organisasi.

Turnover yang tinggi bisa disebabkan karena adanya factor sikap kerja karyawan dalam perusahaan. Menurut robbins (2007), ada tiga sikap kerja yang utama dalam kehidupan berorganisasi yaitu : Kepuasan kerja, keterlibatan kerja dan komitmen karyawan pada organisasi tempat mereka berada, dimana menurut robbins (2007) factor-faktor ini bisa membuka jalan evaluasi positif atau negative bagi seorang karyawan, dengan kata lain keputusan untuk pindah atau bertahan disuatu perusahaan dapat ditentukan oleh faktor-faktor sikap kerja diatas. 
Berdasarkan uraian pada latar belakang dapat dirumuskan permasalahan sebagai berikut :

1. Apakah kepuasan kerja, keterlibatan kerja dan komitmen pada organisasi berpengaruh signifikan secara simultan terhadap turnover intentions di PT Sumber Purnama Sakti.

2. Apakah kepuasan kerja,keterlibatan kerja dan komitmen pada organsasi berpengaruh secara parsial terhadap turnover intentions di PT Sumber Purnama Sakti.

3. Manakah diantara kepuasan kerja, keterlibatan kerja dan komitmen organisasi yang mempunyai pengaruh paling dominan terhadap turnover intentions di PT Sumber Purnama Sakti.

\section{TINJAUAN TEORITIS}

\section{Kepuasan Kerja}

Kepuasan kerja adalah keadaan emosional yang ditunjukkan oleh seorang karyawan terhadap pekerjaannya berupa perasaan menyenangkan atau tidak menyenangkan dalam menjalankan pekerjaannya tersebut. Handoko (1998).

Adapun menurut Robbin ( 2001 : 91 ) Kepuasan kerja adalah merujuk pada sikap umum seorang individu terhadap pekerjaannya. Seseorang dengan tingkat kepuasan kerja yang tinggi menunjukkan sikap positif terhadap kerja itu sedangkan seseorang yang tidak puas dengan pekerjaannya menunjukkan sikap yang negatif terhadap pekerjaan itu.

Menurut pandangan Luthans (1998 : 114), kepuasan kerja merupakan hasil persepsi karyawan tentang bagaimana pekerjaan mereka dapat memberikan sesuatu yang dianggap penting. Karena ini adalah masalah persepsi, maka kepuasan kerja yang ditunjukkan oleh seseorang berbeda dengan orang lain, karena hal yang dianggap penting oleh masing-masing orang berbeda. Luthans (2006 : 114) membagi kepuasan kerja menjadi tiga dimensi :

1. Kepuasan kerja adalah suatu emosi yang merupakan respon terhadap situasi kerja. Hal ini tidak dapat dilihat, tetapi hanya dapat diduga. Atau hal ini tidak dapat dinyatakan, tetapi akan tercermin dalam sikap karyawan.

2. Kepuasan kerja dinyatakan dengan perolehan hasil yang sesuai, atau bahkan melebihi dari yang diharapkan, misalnya seseorang bekerja sebaik yang mampu dilakukannya dan berharap mendapat imbalan yang sepadan.

3. Kepuasan kerja biasanya dinyatakan dalam sikap. Seseorang yang merasa puas dengan pekerjaannya akan tercermin melalui sikap, misalnya dia akan semakin loyal pada perusahaan, bekerja dengan baik, berdedikasi tinggi, tertib serta sikap-sikap lain yang bersifat positif.

\section{Keterlibatan Kerja}

Keterlibatan kerja yakni mengukur sejauh mana derajat seseorang memihak secara psikologis terhadap pekerjaannya, berpartisipasi aktif didalamnya dan menganggap tingkat kinerjanya yang dipersespsikan penting sebagai harga diri (Robbins 2001:19). Karyawan dengan tingkat keterlibatan yang tinggi dengan kuat akan memihak pada jenis kerja yang dilakukan dan benar-benar perduli dengan jenis kerja itu misalnya karyawan menyumbangkan ide untuk kemajuan perusahaan, dengan senang hati memenuhi peraturan serta akan mendukung kebijakan perusahaan dan lainlain. Sebaliknya karyawan yang kurang terlibat dengan pekejaannya adalah karyawan yang kurang memihak kepada perusahaan. Lodahl dan Kejner (dalam Cohen, 2003) mendefinisikan keterlibatan kerja sebagai internalisasi nilai-nilai tentang kebaikan pekerjaan atau pentingnya pekerjaan bagi keberhargaan seseorang.

Rabinowitz dan Hall (dalam Kanungo, 1982) mendefinisikan keterlibatan keja ke dalam dua kategori. Pertama, keterlibatan kerja dipandang sebagai suatu "performance self-esteem contingency," dimana menurut definisi ini, keterlibatan kerja adalah tingkat sampai sejauh mana harga diri (self-esteem) individu dipengaruhi oleh tingkat performansinya ketika bekerja. Sehingga, keterlibatan kerja yang lebih rendah atau yang lebih tinggi menunjukkan harga diri yang lebih rendah atau yang lebih tinggi yang 
diperoleh ketika bekerja. Kedua, keterlibatan kerja sebagai suatu identifikasi psikologis dengan pekerjaan seseorang.

\section{Komitmen pada Organisasi}

Komitmen

didefinisikan sebagai tingkat kekerapan identifikasi dan tingkat keterikatan individu kepada organisasi tertentu yang dicerminkan dengan karakteristik: (a) adanya keyakinan yang kuat dan penerimaan atas nilai dan tujuan organisasi, (b) adanya keinginan yang pasti untuk mempertahankan keikutsertaan dalam organisasi Mobley (1998).

Sementara menurut William dan Hazer (1986); Mowday (1987) Komitmen organisasional didefinisikan tingkat kekerapan identifikasi dan keterikatan individu terhadap organisasi yang dimasukinya, dimana karakteristik komitmen organisasional antara lain adalah loyalitas seseorang terhadap organisasi, kemauan untuk mempergunakan usaha atas nama organisasi, kesuaian antara tujuan seseorang dengan tujuan organisasi.

Secara umum komitmen pada organisasi diartikan sebagai suatu keadaan dimana seorang karyawan memihak pada suatu organisasi tertentu dan tujuantujuannya, serta berniat memelihara keanggotaan dalam organisasi itu. Komitmen organisasi yang tinggi berarti pemihakan pada organisasi yang mempekerjakannya.

Menurut Luthans (2006) komitmen pada organisasi sebagai sikap, yaitu :

1. Keinginan kuat untuk tetap sebagai anggota organisasi tertentu.

2. Perasaan bangga menjadi bagian organisasi

3. Keinginan untuk berusaha keras sesuai keinginan organisasi.

4. Keyakinan tertentu, dan penerimaan nilai dan tujuan organisasi.

\section{Intensi Keluar (Turnover Intensions)}

Intensi adalah niat atau keinginan yang timbul pada individu untuk melakukan sesuatu, sementara turnover adalah berhentinya seseorang karyawan dari tempat bekerja. Dengan demikian, turnover intentions (intensi keluar) adalah kecenderungan atau niat karyawan untuk berhenti bekerja dari pekerjaannya (Zeffane, 1994).

Intensi keluar (turnover intensions) juga dapat diartikan sebagai pergerakan tenaga kerja keluar dari organisasi. Werther dan Davis (1996) mendefinisikan turnover sebagai kesediaan karyawan untuk meninggalkan suatu organisasi dan berpindah ke organisasi lainnya. Turnover dapat terjadi karena adanya tekanan dalam pekerjaan, sehingga turnover bisa menjadi petunjuk adanya tekanan tersebut. Fenomena turnover menunjukkan perubahan-perubahan yang terjadi pada tenaga kerja yaitu tendensi karyawan untuk meninggalkan organisasi dan untuk digantikan oleh yang lain. Turnover bisa terjadi secara sukarela maupun terpaksa. Hasil akhirnya berupa pengunduran diri atas kemauan karyawan sendiri, pensiun, dan pemutusan hubungan kerja.

Tet dan Meyer (1993) telah memberikan definisi turnover intention yaitu niat karyawan untuk meninggalkan organisasi sebagai sadar dan hasrat disengaja dari karyawan untuk meninggalkan organisasi. Sedangkan menurut Martin (1979) intention turnover adalah tingkat keinginan karyawan atau niat untuk meninggalkan organisasi. Menurut Mobley (1986) keluar masuknya karyawan dan perilaku seperti kemangkiran dan kelesuan seringkali dikelompokkan dalam perilaku pengunduran diri atau disebut pula sebagai keinginan berhenti bekerja (turnover intent). Menurut Robbins (1998) menyatakan bahwa karyawan yang tidak terpuaskan oleh pekerjaan atau faktor lainnya yang berkaitan dengan pekerjaan mereka, akan dapat mengurangi komitmen mereka terhadap organisasi atau perusahaan.

Ketidakpuasan mereka umumnya selalu dikaitkan dengan masalah penurunan kinerja yang termasuk di dalamnya terjadi kelambatan dalam bekerja, tingkat perputaran karyawan yang tinggi dan tingkat ketidakhadiran atau kemangkiran yang tinggi. Sebagaimana diketahui diatas, intention to leave karyawan dapat terjadi di antara karyawan yang merasa puas karena tertarik oleh harapan yang sangat positif mengenai pekerjaan di luar atau yang memutuskan untuk 
mengikuti nilai yang tak ada kaitannya dengan pekerjaan. Apabila seseorang ingin meninggalkan pekerjaan yang tidak disenangi (tetapi terkendala oleh beberapa sebab, misalnya: kurangnya pekerjaan yang menarik, karier pasangan hidup), maka bentuk intention to leave dan pengunduran diri dapat berupa kemangkiran dan kelesuan. Robbins (2007) menyatakan bahwa banyak faktor yang menyebabkan karyawan berpindah dari tempat kerjanya namun faktor yang utama adalah karena adanya factor sikap kerja adalah :

\section{Kepuasan kerja}

Pada tingkat individual, kepuasan merupakan variabel psikologis yang paling sering diteliti dalam suatu model intention to leave. Aspek kepuasan yang ditemukan berhubungan dengan keinginan individu untuk meninggalkan organisasi meliputi kepuasan akan upah dan promosi, kepuasaan atas supervise yang diterima, kepuasan dengan rekan kerja, dan kepuasan akan pekerjaan dan isi kerja.

2. Komitmen pada organisasi

Karena hubungan kepuasan kerja dan keinginan meninggalkan tempat kerja hanya menerangkan sebagian kecil varian, maka jelas model proses intention to leave karyawan harus menggunakan variabel lain di luar kepuasan kerja sebagai satu- satunya variabel penjelas. memasukkan konstruk komitmen organisasional sebagai konsep yang turut menjelaskan proses tersebut Sebagai bentuk perilaku, komitmen organisasional dapat dibedakan dari kepuasan kerja. Komitmen mengacu pada respon emosional (affective) individu kepada keseluruhan organisasi, sedangkan kepuasan mengarah pada respon emosional atas aspek khusus dari pekerjaan

\section{Keterlibatan Kerja}

Keterlibatan kerja adalah ukuran sejauh mana derajat seseorang memihak secara psikologis terhadap pekerjaannya, berpartisipasi aktif didalamnya dan menganggap tingkat kinerjanya yang dipersespsikan penting sebagai harga dirinya

\section{METODE PENELITIAN}

\section{Jenis Penelitian}

Jenis penelitian yang gunakan dalam penelitian ini adalah penelitian kausalitas.
Menurut Umar (2003 : 30) penelitian kausalitas adalah "penelitian yang bertujuan untuk menganalisis hubungan antara satu variabel dengan variable lainnya atau bagaimana suatu variabel mempengaruhi variabel lain.

\section{Lokasi / Objek Penelitian.}

Obyek penelitian ini adalah PT Sumber Purnama Sakti Mataram yang terletak dijalan Panca Usaha no 34 Mataram .

\section{Populasi dan Responden \\ Populasi}

Populasi dalam penelitian ini adalah semua karyawan dengan status karyawan tetap disemua bagian. Adapun jumlah populasi dalam penelitian ini sebanyak 120 orang.

\section{Responden}

Dalam penelitian ini metode penarikan responden yang digunakan adalah metode sensus. Metode sensus adalah penarikan jumlah sampel atau responden dengan melibatkan seluruh anggota populasi.

\section{Jenis Dan Sumber Data}

\section{Jenis Data}

Jenis data yang digunakan dalam penelitian ini adalah :

1. Data Kuantitatif yaitu data yang berupa angka-angka dan dapat dianalisa secara sistematis seperti jumlah atau satuan tertentu dalam penelitian ini berupa perkembangan tingkat turnover karyawan PT Sumber Purnama Sakti Mataram.

2. Data kualitatif yaitu data yang tidak berupa angka-angka namun berupa keterangan-keterangan seperti gambaran umum PT Sumber Purnama Sakti Mataram

\section{Sumber data}

Sumber data dalam penelitian ini adalah :

1. Data primer

Merupakan data yang diperoleh secara langsung dari sumber data, diamati dan dicatat untuk pertama kalinya (Marzuki, 1995). Adapun data primer adalah data yang dikumpulkan melalui penyebaran kuesioner kepada karyawan PT Sumber Purnama Sakti Mataram yang telah dibuat dan disusun dalam bentuk pertanyaan yang berisi rangkaian pertanyaan. Yang menjadi dasar dari metode ini adalah self report dari subjeknya. Dengan 
dasar meode ini diharapkan dapat mengenai sasaran karena subyek dianggap paling mengetahui dirinya sendiri. Data yang digunakan mengenai kepuasan kerja karyawan dan komitmen organisasional.

\section{Data Sekunder}

Data sekunder adalah data yang merupakan sumber data penelitian yang diperoleh peneliti secara tidak langsung melalui perantara (diperoleh dan dicatat oleh pihak lain). Adapun data sekunder yang digunakan dalam penelitian ini adalah data mengenai literaturliteratur maupun informasi yang menunjang lainnya seperti data dokumen-dokumen di PT Sumber Purnama Sakti Mataram yang diperlukan dalam penelitian ini, data tentang profil dan Struktur organisasi serta data turnover selama lima tahun.

\section{Teknik pengumpulan data}

Teknik Pengumpulan data yang digunakan dalam penelitian ini adalah :

1. Metode Observasi.

Adalah pengamatan dan pencatatan secara sistematisk terhadap gejala yang tampak pada objek penelitian, (Rachman, 1999 : 77). Dalam hal ini penulis melakukan pengamatan secara langsung kepada objek yang diteliti.

2. Metode Angket/kuesioner

Adalah teknik pengumpulan data yang dilakukan dengan cara memberikan seperangkat pertanyaan atau pernyataan kepada orang lain yang menjadi responden untuk dijawabnya. Dalam hal ini penulis menyebarkan angket kepada karyawan PT Sumber Purnama Sakti Mataram.

\section{Metode Dokumentasi}

Metode dokumentasi yaitu mencari data mengenai hal-hal atau variabel yang berupa catatan, transkrip, buku, surat kabar, majalah, prasasti, notulen rapat, lengger, agenda, dan sebagainya, (Arikunto, 2002:206).

\section{Studi Pustaka}

Kegiatan mengumpulkan bahan-bahan yang berhubungan dengan penelitian yang diperoleh dari jurnal-jurnal penelitian terdahulu, literatur-literatur serta sumbersumber lain yang dapat dijadikan bahan masukan untuk dapat mendukung penelitian ini.

\section{Identifikasi Variabel}

Berdasarkan permasalahan yang

dikemukakan, variabel-variabel yang dianalisis dalam penelitian ini dapat diidentifikasikan sebagai berikut :

1. Kepuasan Kerja (X1)

2. Keterlibatan Kerja (X2)

3. Komitmen Organisasi (X3)

4. Turnover intentions $(\mathrm{Y})$

\section{Klasifikasi Variabel}

Variabel-variabel yang telah diidentifikasikan dapat diklasifikasikan sebagai berikut:

1.Variabel Independen

Variabel ini disebut juga variabel bebas yaitu variabel yang mempengaruhi variabel terikat. Yang menjadi variabel bebas adalah Kepuasan kerja (X1), Keterlibatan kerja (X2) dan Komitmen organisasi ( X3)

2. Variabel Dependen

Variabel dependen atau terikat merupakan variabel yang nilainya dipengaruhi atau tergantung oleh variabel bebas. Yang menjadi variabel terikat dalam penelitian ini adalah keinginan berpindah kerja (Turnover intentions)

\section{Definisi Operasional Variabel}

\section{Kepuasan Kerja}

Kepuasan kerja merujuk pada persepsi responden terhadap sikap responden terhadap pekerjaannya. Seseorang dengan tingkat kepuasan kerja yang tinggi menunjukkan sikap positif terhadap kerja itu sedangkan seseorang yang tidak puas dengan pekerjaannya menunjukkan sikap yang negatif terhadap pekerjaan itu. Untuk mengukur kepuasan kerja menggunakan indikator : kesesuaian pribadi dengan pekerjaan,perolehan hasil (upah),kondisi kerja ,disiplin dan kesempatan yang sama dalam hal peningkatan karir. Robbins (dalam Malayu 2005)

2. Keterlibatan Kerja

Persepsi respoden terhadap sejauh mana derajat responden berpihak secara psikologis pada pekerjaannya dan menganggap tingkat kinerjanya penting bagi harga dirinya. Untuk mengukur variable keterlibatan kerja adalah dengan indicator sebagai berikut : sejauh mana responden menilai tingkat kerjanya penting bagi harga 
dirinya,sejauh mana tingkat keperdulian responden terhadap pekerjaannya, dan sejauh mana responden berpartisipasi aktif dalam pekerjaannya (robbins 2001:19)

3. Komitmen Organisasi

Komitmen pada organisasi diartikan sebagai suatu persepsi keadaan dimana seorang karyawan memihak pada suatu organisasi tertentu dan tujuan-tujuannya, serta berniat memelihara keanggotaan dalam organisasi itu. Variabel komitmen organisasional dapat diukur dengan : perasaan bangga menjadi bagian dari organisasi,kebanggan terhadap organisasi,keperdulian terhadap organisasi,hasrat yang kuat bekerja untuk organiasasi dan kepercayaan yang kuat terhadap nilai-nilai organisasi. Luthans (2006) 4.Turnover Intention

turnover intentions (intensi keluar) adalah kecenderungan atau niat karyawan untuk berhenti bekerja dari pekerjaannya. Intensi keluar (turnover intensions) juga dapat diartikan sebagai pergerakan tenaga kerja keluar dari organisasi.adapun untuk mengukur turnover intentions adalah dengan variabel berikut : kecenderungan individu untuk berpikir untuk meninggalkan tempat bekerja yang sekarang dan kemungkinan individu akan mencari pekerjaan pada perusahaan lain. Zeffane (1994)

\section{Pengukuran Variabel}

Dalam penelitian ini setiap variable yang diteliti diberikan skor yang mengacu pada skala Likert. Skala likert merupakan teknik self report bagi pengukuran sikap dimana subyek diminta mengindikasikan tingkat kesetujuan atau ketidaksetujuan mereka terhadap masing-masing pernyataan. Untuk memberikan pembobotan terhadap masingmasing variable menggunakan skala lima yang terdiri atas : Sangat Setuju (SS), Setuju (S) ,Netral (N), Kurang Setuju (KS) ,Tidak Setuju Sekali (TSS).

Adapun skor yang digunakan adalah :

a. Skor 5 (lima),bila responden memilih sangat setuju (SS)

b. Skor 4 (empat),bila responden memilih setuju (S)

Jurnal Pendidikan Mandala c. Skor 3 (tiga),bila responden memilih Netral (N)

d. Skor 2 (dua), bila responden memilih kurang setuju (KS)

e. Skor 1 (satu) bila responden memilih tidak setuju sekali (TSS)

\section{PEMBAHASAN}

Hasil Analisis Regresi Linier Berganda

Analisis ini menggunakan program SPSS

16.00. Berdasarkan lampiran 2, berikut adalah hasil dan penjelasannya :

Tabel 4.1 : Hasil Analisis Regresi Linear Berganda

Hasil Analisis Regresi Linier Berganda

Analisis ini menggunakan program SPSS 16.00. Berdasarkan lampiran 2, berikut adalah hasil dan penjelasannya :

Tabel 4.14 : Hasil Analisis Regresi Linear Berganda

\begin{tabular}{|c|c|c|c|}
\hline Variabel Bebas & Koefisien & $\mathbf{t}_{\text {hitung }}$ & $\operatorname{Sig} \mathrm{Z}$ \\
\hline (Constant) & 4.745 & 12.524 & 0,000 \\
\hline $\mathrm{X}_{1}$ (Kepuasaan Kerja) & -0.233 & -2.530 & 0,013 \\
\hline $\mathrm{X}_{2}$ (Keterlibatan Kerja) & $-0,105$ & -1.643 & 0,103 \\
\hline $\begin{array}{l}\text { X3 (Komitmen pada } \\
\text { organisasi ) }\end{array}$ & $-0,027$ & -0.259 & 0,026 \\
\hline R Square & \multicolumn{3}{|l|}{0,640} \\
\hline F hitung & \multicolumn{3}{|l|}{3.484} \\
\hline Sign F & \multicolumn{3}{|l|}{0,018} \\
\hline Durbin Watson (DW) & \multicolumn{3}{|l|}{1.850} \\
\hline
\end{tabular}

Sumber : lampiran 6

Dari tabel di atas dapat dibentuk model persamaan regresi yaitu :

$\mathrm{Y}=4.745-0,233 \mathrm{X} 1-0,105 \mathrm{X} 2$ - 0,027 X3

+ ei

\section{Interpretasi Data}

Variabel Kepuasan Kerja (X1)

Dari model persamaan regresi tersebut diatas maka dapat diketahui bahwa kepuasan kerja (X1) berpengaruh negatif terhadap turnover intentions yang ditunjukkan dengan nilai koefisien $(-0,233)$ ini mengartikan bahwa semakin seorang karyawan merasa tidak puas dengan perusahaannya tempat dia bekerja maka semakin besar pula niat karyawan tersebut untuk meninggalkan pekerjaannya.

Mobley dkk (1978) dalam Novliadi (2007) mengemukakan bahwa kepuasan kerja memiliki hubungan erat terhadap pikiran untuk berhenti kerja dan intensi 
untuk mencari pekerjaan lain. Intensi untuk berhenti pada akhirnya memiliki hubungan signifikan terhadap turnover sebenarnya. Robbins (2003) menjelaskan bahwa kepuasan kerja dihubungkan negatif dengan keluarnya karyawan, tetapi faktorfaktor lain seperti pasar kerja, kesempatan kerja alternatif dan panjangnya masa kerja merupakan kendala penting untuk meninggalkan pekerjaan yang ada

\section{Variabel Keterlibatan Kerja (X2)}

Dari tabel hasil analisis regresi linear berganda diatas dapat diketahui variabel X2 (keterlibatan kerja) menunjukkan pengaruh yang negatif yakni dengan koefisien sebesar $(-0,105)$ artinya semakin keterlibatan kerja seorang karyawan dalam suatu perusahaan itu rendah maka semakin tinggi pula niat karyawan tersebut untuk meninggalkan perusahaan tersebut.

Menurut Blau dan Boal (1987, dalam Kartiningsih 2007) keterlibatan kerja pada prakteknya berkaitan dengan tingkat absensi, kadar permohonan berhenti bekerja dan berkeinginan berpartisipasi dalam tim atau kelompok kerja. Apabila tingkat keterlibatan kerja tidak diperhatikan akan menyebabkan terjadinya kemangkiran (absen) dan turnover intention yang tinggi (Robbins dan Caulter,2007; Faslah, 2007). Menurut Mobley (1986) menyatakan keterlibatan kerja berpengaruh negatif dan signifikan terhadap turnover intention

Pendapat ini didukung oleh G. J. Blau (2003) yang menyatakan bahwa tingkat keterlibatan kerja yang tinggi ditemukan secara signifikan berkaitan dengan kemangkiran dan tingkat permohonan berhenti yang lebih rendah. Ini dapat disimpulkan bahwa secara signifikan karyawan yang memiliki keterlibatan kerja yang tinggi akan berpartisipasi aktif dalam pekerjaannya dan menunjukkan integritas karyawan pada pekerjaannya dan kesediaan karyawan untuk melakukan pekerjaannya dengan lebih banyak waktu sehingga mengurangi tingkat kemangkiran dan sedikit karyawan yang mempunyai keinginan untuk berpindah (Turnover intention).

Variabel komitmen pada organisasi
Komitmen pada organisasi diartikan sebagai suatu keadaan dimana seorang karyawan memihak pada suatu organisasi tertentu dan tujuan-tujuannya, serta berniat memelihara keanggotaan dalam organisasi itu (Luthans). Adapun ciri-ciri orang yang mempunyai komitmen pada organisasi adalah sebagai berikut:

1. Keinginan kuat untuk tetap sebagai anggota organisasi tertentu.

2. Keinginan untuk berusaha keras sesuai keinginan organisasi.

3.Keyakinan tertentu, dan penerimaan nilai dan tujuan organisasi.

Keinginan karyawan untuk mempertahankan keanggotaannya ini menyebabkan komitmen sering dikaitkan dengan masalah turnover, karena karyawan yang komitmennya tinggi memiliki tingkat kecenderungan untuk mengundurkan diri rendah. Sehingga komitmen sering dipandang sebagai jalan keluar atas pemecahan masalah turnover.

Dari model persamaan regresi diatas dapat diketahui bahwa koefisien untuk X3 (komitmen pada organisasi) adalah sebesar (0,027) menunjukkan adanya pengaruh yang negative antara komitmen pada organisasi dengan niat karyawan untuk berhenti bekerja di perusahaan, yang artinya semakin rendah komitmen pada organisasi seorang karyawan maka tinggi pula niat karyawan tersebut untuk berhenti bekerja.

\section{Koefisien determinasi}

Koefisien determinasi ( $\mathrm{R}$ Square) sebesar 0,640 artinya hanya $64 \%$ variabel $Y$ dapat dijelaskan oleh X1, X2, X3. Sisanya sebesar $36 \%$ (100\%- $64 \%)$ dijelaskan oleh variabel lain di luar model.

Adapun menurut teori bahwa faktor lain (variabel lain) yang diduga menjadi penyebab turnover intentions selain dari kepuasan kerja,keterlibatan kerja dan komitmen pada organisasi adalah :

1. Job insecurity

Ashford dkk (1989) mengatakan bahwa job insecurity merupakan tingkatan dimana para pekerja merasa pekerjaannya terancam dan mereka merasa tidak berdaya untuk untuk melakukan apapun terhadap situasi tersebut. 
Joelsen dan walquish (dalam hartley $\mathrm{dkk}, 1991)$ job insecurity merupakan pemahaman individual pekerja sebagai tahap pertama dalam proses kehilangan pekerjaan. Kenyataannya jumlah populasi yang mengalami job insecurity adalah selalu dalam jumlah yang lebih besar daripada pekerja yang benar-benar kehilangan pekerjaan.

\section{Stress kerja}

Stress adalah suatu kondisi ketegangan yang mempengaruhi emosi, proses berpikir dan kondisi seseorang. Berbagai studi telah dilakukan oleh para peneliti yang mengkaji hubungan antara stress kerja dengan turnover intentions. (Hemingtton dan Smith, alam nugroho) menyebutkan bahwa keduanya saling berhubungan karena stress kerja dapat menyebabka ketidakpuasan (job dissatisfaction) dan dapat meingkatkan jumlah karyawan yang keluar.

Chen et al., (2004) dalam penelitiannya yang berjudul "Modelling Job Stress As Mediation Role In Predicting Turnover Intentions". Menemukan bahwa stress kerja berpengaruh signifikan positif terhadap turnover intentions dan Penelitian lain yang dilakukan oleh Wefald (2008) dengan judul " $A$ structural model of workload, job attitudes, stress and turnover intentions" menemukan bahwa steress kerja berpengaruh positif terhadap turnover intentions.

\subsubsection{Pengujian Hipotesis \\ Pengujian secara Simultan}

Dari hasil pengujian hipotesis diperoleh $\mathrm{F}$ hitung sebesar 3.484 yang lebih besar dari $\mathrm{f}$ tabel yaitu 3,07 tabel dengan nilai signifikansi $0,018<0,05$ ini mengindikasikan bahwa secara serentak kepuasan kerja,keterlibatan kerja dan komitmen organisasi berpengaruh signifikan terhadap turnover intentions di PT Sumber Purnama Sakti Mataram

Variabel kepuasan kerja,keterlibatan kerja dan komitmen pada organisasi secara bersama-sama mempengaruhi turnover intentions para karyawan di PT Sumber Purnama Sakti Mataram . Hal ini senada dengan pendapat para ahli bahwa ketiga variabel tersebut bisa menjadi pembuka jalan evaluasi positif maupun negatif bagi seorang karyawan atau dengan kata lain keputusan untuk pindah atau bertahan disuatu perusahaan ditentukan oleh faktor-faktor tersebut diatas (Robbins, 2007)

Pengujian secara Parsial

Hasil Uji Parsial Variabel Kepuasan Kerja

Dari hasil perhitungan didapat nilai $\mathrm{t}$ hitung sebesar -2.530 dengan tingkat signifikansi sebesar 0,013 yang lebih kecil dari 0,05 , hal ini mengartikan bahwa terdapat pengaruh yang signifikan antara kepuasan kerja dengan turnover intentions karyawan di PT Sumber Purnama Sakti

Kepuasan kerja pada karyawan memiliki arti yang sangat penting bagi perusahaan. Karyawan yang merasa puas pastinya akan bertahan di perusahaan itu dan mampu bekerja secara produktif. Ketidakpuasan kerja telah sering diidentifikasikan sebagai suatu alasan yang penting yang menyebabkan individu meninggalkan pekerjaannya (Robbins, 2001 : 91).

Hasil penelitian ini juga didukung dengan penelitian sebelumnya yang dilakukan oleh Andini (2008) yang melakukan penelitian dengan judul “ Analisis pengaruh kepuasan Gaji, kepuasan kerja dan komitmen organisasional terhadap turnover intentions". Penelitian ini yang menyebutkan bahwa kepuasan kerja berpengaruh negative terhadap turnover intentions yang ditunjukkan dengan nilai $\mathrm{CR}=-4,875$.

\section{Hasil Uji Parsial Variabel Keterlibatan Kerja}

Dari hasil perhitungan didapat nilai $t$ hitung sebesar -1.643 dengan signifikansi 0,103, hasil ini mengindikasikan bahwa tidak terdapat pengaruh yang signifikan antara keterlibatan kerja dengan variabel turnover intentions di PT Sumber Purnama Sakti Mataram

Secara terpisah (parsial), keterlibatan kerja tidak berpengaruh secara signifikan terhadap keinginan seorang karyawan untuk berhenti kerja. Seseorang karyawan bisa saja mempunyai keterlibatan kerja yang rendah namun hal itu tidak serta merta membuat seseorang akan keluar dari pekerjaannya karena faktor-faktor seperti pasar kerja, 
kesempatan kerja, alternatif dan usia merupakan hal yang penting untuk dipikirkan sebelum seorang akan meninggalkan pekerjaannya. Robbins (2003)

\section{Hasil Uji Parsial Variabel Komitmen Pada Organisasi}

Dari hasil perhitungan didapat hasil untuk varabel komitmen pada organisasi sebesar $-0,259$ dengan tingkat signifikansi sebesar 0,026 yang artinya terdapat pengaruh yang signifikan antara komitmen pada organisasi dengan turnover intentions di PT Sumber Purnama Sakti Mataram

Menurut Mobley (1979) pada Lum et al., (1998) komitmen organisasional diartikan yaitu adanya keinginan yang pasti untuk mempertahankan keikutsertaannya dalam organisasi. Individu yang rnemiliki komitmen organisasional rendah cenderung untuk mencari kesernpatan kerja yang lebih baik dan keluar dan pekerjaannya karena dalam diri mereka telah tertanam keinginan untuk keluar organisasi.

Beberapa penelitian seperti Lum et al., (1998); Lee et al.,(1992); Lee \& Mowday (1987) menyimpulkan bahwa Individu yang mempunyai komitmen pada organisasi yang tinggi akan berpengaruh terhadap intensi keluar yang semakin rendah.

Dari nilai t hitung dapat kita ketahui bahwa kepuasan kerja merupakan factor paling dominan yang paling berpengaruh terhadap niat seseorang untuk berhenti bekerja di PT Sunber Purnama Sakti Mataram yaitu sebesar -2.530 bila dibandingkan dengan keterlibatan kerja dan komitmen pada organisasi

Hal ini terjadi karena rata-rata usia karyawan PT Sumber Purnama Sakti adalah relatif dalam usia muda. Maier (1971) mengemukakan pekerja muda mempunyai tingkat turnover yang lebih tinggi daripada pekerja-pekerja yang lebih tua.

Penelitian-penelitian terdahulu menunjukkan adanya hubungan yang signifikan antara usia dan intensi turnover dengan arah hubungan negatif. Artinya semakin tinggi usia seseorang, semakin rendah intensi turnovernya (dalam Mobley,1986). Karyawan yang lebih muda lebih tinggi kemungkinan untuk keluar. Salah satu karakteristik pekerja dalam usia muda adalah mereka mempunyai pola konsumtif yang tinggi sehingga kepuasan merupakan faktor utama yang diinginkan oleh mereka Gilmer (1966). Jika mereka merasa puas dengan pekerjaannya maka faktor-faktor lain seperti keterlibatan kerja dan komitmen pada organisasi akan mengikuti

Adanya kepuasan kerja yang dirasakan akan memberikan pengaruh yang positif. Karyawan akan selalu termotivasi untuk selalu bersemangat sehingga kinerja akan meningkat. Dengan kata lain dapat disimpulkan bahwa sebelum seorang karyawan mempunyai tingkat keterlibatan kerja dan komitmen pada organisasi, maka yang menjadi ukuran pertama mereka adalah tingkat kepuasan kerja, karena didalam kepuasan kerja terdapat hal-hal yang menjadi tujuan utama seorang pekerja sehingga mereka mau bekerja seperti gaji, kesempatan untuk maju, pengakuan dan lain sebagainya. Jika apa yang menjadi harapan seorang karyawan bisa terpenuhi maka karyawan tersebut akan memiliki motivasi yang kuat untuk bekerja yang akan memberikan dampak pada keterlibatan kerja yang tinggi dan meningkatnya komitmen pada organisasi dan pada ahirnya menurunkan tingkat permintaan untuk berhenti kerja.

\section{Interpretasi Data}

\section{Variabel Kepuasan Kerja (X1)}

Dari model persamaan regresi tersebut diatas maka dapat diketahui bahwa kepuasan kerja (X1) berpengaruh negatif terhadap turnover intentions yang ditunjukkan dengan nilai koefisien $(-0,253)$ ini mengartikan bahwa semakin seorang karyawan merasa tidak puas dengan perusahaannya tempat dia bekerja maka semakin besar pula niat karyawan tersebut untuk meninggalkan pekerjaannya.

Mobley dkk (1978) dalam Novliadi (2007) mengemukakan bahwa kepuasan kerja memiliki hubungan erat terhadap pikiran untuk berhenti kerja dan intensi untuk mencari pekerjaan lain. Intensi untuk berhenti pada akhirnya memiliki hubungan signifikan terhadap turnover 
sebenarnya. Robbins (2003) menjelaskan bahwa kepuasan kerja dihubungkan negatif dengan keluarnya karyawan, tetapi faktorfaktor lain seperti pasar kerja, kesempatan kerja alternatif dan panjangnya masa kerja merupakan kendala penting untuk meninggalkan pekerjaan yang ada

\section{Variabel Keterlibatan Kerja (X2)}

Dari tabel hasil analisis regresi linear berganda diatas dapat diketahui variabel X2 (keterlibatan kerja) menunjukkan pengaruh yang negatif yakni dengan koefisien sebesar $(-0,142)$ artinya semakin keterlibatan kerja seorang karyawan dalam suatu perusahaan itu rendah maka semakin tinggi pula niat karyawan tersebut untuk meninggalkan perusahaan tersebut.

Menurut Blau dan Boal (1987, dalam Kartiningsih 2007) keterlibatan kerja pada prakteknya berkaitan dengan tingkat absensi, kadar permohonan berhenti bekerja dan berkeinginan berpartisipasi dalam tim atau kelompok kerja. Apabila tingkat keterlibatan kerja tidak diperhatikan akan menyebabkan terjadinya kemangkiran (absen) dan turnover intention yang tinggi (Robbins dan Caulter,2007; Faslah, 2007). Menurut Mobley (1986) menyatakan keterlibatan kerja berpengaruh negatif dan signifikan terhadap turnover intention

Pendapat ini didukung oleh G. J. Blau (2003) yang menyatakan bahwa tingkat keterlibatan kerja yang tinggi ditemukan secara signifikan berkaitan dengan kemangkiran dan tingkat permohonan berhenti yang lebih rendah. Ini dapat disimpulkan bahwa secara signifikan karyawan yang memiliki keterlibatan kerja yang tinggi akan berpartisipasi aktif dalam pekerjaannya dan menunjukkan integritas karyawan pada pekerjaannya dan kesediaan karyawan untuk melakukan pekerjaannya dengan lebih banyak waktu sehingga mengurangi tingkat kemangkiran dan sedikit karyawan yang mempunyai keinginan untuk berpindah (Turnover intention).

\section{Variabel komitmen pada organisasi}

Komitmen pada organisasi diartikan sebagai suatu keadaan dimana seorang karyawan memihak pada suatu organisasi tertentu dan tujuan-tujuannya, serta berniat memelihara keanggotaan dalam organisasi itu (Luthans). Adapun ciri-ciri orang yang mempunyai komitmen pada organisasi adalah sebagai berikut :

1. Keinginan kuat untuk tetap sebagai anggota organisasi tertentu.

2. Keinginan untuk berusaha keras sesuai keinginan organisasi.

3.Keyakinan tertentu, dan penerimaan nilai dan tujuan organisasi.

$\begin{array}{ccr}\text { Keinginan } & \text { karyawan } & \text { untuk } \\ \text { mempertahankan } & \text { keanggotaannya } & \text { ini }\end{array}$ menyebabkan komitmen sering dikaitkan dengan masalah turnover, karena karyawan yang komitmennya tinggi memiliki tingkat kecenderungan untuk mengundurkan diri rendah. Sehingga komitmen sering dipandang sebagai jalan keluar atas pemecahan masalah turnover.

Dari model persamaan regresi diatas dapat diketahui bahwa koefisien untuk X3 (komitmen pada organisasi) adalah sebesar ($0,351)$ menunjukkan adanya pengaruh yang negative antara komitmen pada organisasi dengan niat karyawan untuk berhenti bekerja di perusahaan, yang artinya semakin rendah komitmen pada organisasi seorang karyawan maka tinggi pula niat karyawan tersebut untuk berhenti bekerja.

\section{Koefisien determinasi}

Koefisien determinasi ( $\mathrm{R}$ Square) sebesar 0,610 artinya hanya $61 \%$ variabel Y dapat dijelaskan oleh X1, X2, X3. Sisanya sebesar $39 \%$ (100\%- $61 \%)$ dijelaskan oleh variabel lain di luar model.

Adapun menurut teori bahwa faktor lain (variabel lain) yang diduga menjadi penyebab turnover intentions selain dari kepuasan kerja,keterlibatan kerja dan komitmen pada organisasi adalah :

3. Job insecurity

Ashford dkk (1989) mengatakan bahwa job insecurity merupakan tingkatan dimana para pekerja merasa pekerjaannya terancam dan mereka merasa tidak berdaya untuk untuk melakukan apapun terhadap situasi tersebut.

Joelsen dan walquish (dalam hartley $\mathrm{dkk}, 1991)$ job insecurity merupakan pemahaman individual pekerja sebagai tahap 
pertama dalam proses kehilangan pekerjaan. Kenyataannya jumlah populasi yang mengalami job insecurity adalah selalu dalam jumlah yang lebih besar daripada pekerja yang benar-benar kehilangan pekerjaan.

4. Stress kerja

Stress adalah suatu kondisi ketegangan yang mempengaruhi emosi, proses berpikir dan kondisi seseorang. Berbagai studi telah dilakukan oleh para peneliti yang mengkaji hubungan antara stress kerja dengan turnover intentions. (Hemingtton dan Smith, alam nugroho) menyebutkan bahwa keduanya saling berhubungan karena stress kerja dapat menyebabka ketidakpuasan (job dissatisfaction) dan dapat meingkatkan jumlah karyawan yang keluar.

Chen et al., (2004) dalam penelitiannya yang berjudul "Modelling Job Stress As Mediation Role In Predicting Turnover Intentions". Menemukan bahwa stress kerja berpengaruh signifikan positif terhadap turnover intentions dan Penelitian lain yang dilakukan oleh Wefald (2008) dengan judul " $A$ structural model of workload, job attitudes, stress and turnover intentions" menemukan bahwa steress kerja berpengaruh positif terhadap turnover intentions.

\section{Pengujian Hipotesis}

\section{Pengujian secara Simultan}

Dari hasil pengujian hipotesis diperoleh $\mathrm{F}$ hitung sebesar 60,371 yang lebih besar dari $\mathrm{f}$ tabel yaitu 3,07 tabel dengan nilai signifikansi $0,000<0,05$ ini mengindikasikan bahwa secara serentak kepuasan kerja,keterlibatan kerja dan komitmen organisasi berpengaruh signifikan terhadap turnover intentions di PT Sumber Purnama Sakti Mataram

Variabel kepuasan kerja,keterlibatan kerja dan komitmen pada organisasi secara bersama-sama mempengaruhi turnover intentions para karyawan di PT Sumber Purnama Sakti Mataram . Hal ini senada dengan pendapat para ahli bahwa ketiga variabel tersebut bisa menjadi pembuka jalan evaluasi positif maupun negatif bagi seorang karyawan atau dengan kata lain keputusan untuk pindah atau bertahan disuatu perusahaan ditentukan oleh faktor-faktor tersebut diatas (Robbins, 2007)

Pengujian secara Parsial Hasil Uji Parsial Variabel Kepuasan Kerja

Dari hasil perhitungan didapat nilai $\mathrm{t}$ hitung sebesar $-6,054$ dengan tingakt signifikansi sebesar 0,000 yang lebih kecil dari 0,05 , hal ini mengartikan bahwa terdapat pengaruh yang signifikan antara kepuasan kerja dengan turnover intentions karyawan di PT Sumber Purnama Sakti

Kepuasan kerja pada karyawan memiliki arti yang sangat penting bagi perusahaan. Karyawan yang merasa puas pastinya akan bertahan di perusahaan itu dan mampu bekerja secara produktif. Ketidakpuasan kerja telah sering diidentifikasikan sebagai suatu alasan yang penting yang menyebabkan individu meninggalkan pekerjaannya (Robbins, 2001 : 91).

Hasil penelitian ini juga didukung dengan penelitian sebelumnya yang dilakukan oleh Andini (2008) yang melakukan penelitian dengan judul " Analisis pengaruh kepuasan Gaji, kepuasan kerja dan komitmen organisasional terhadap turnover intentions". Penelitian ini yang menyebutkan bahwa kepuasan kerja berpengaruh negative terhadap turnover intentions yang ditunjukkan dengan nilai $\mathrm{CR}=-4,875$.

\section{Hasil Uji Parsial Variabel Keterlibatan Kerja}

Dari hasil perhitungan didapat nilai $\mathrm{t}$ hitung sebesar -1,957 dengan signifikansi 0,053 , hasil ini mengindikasikan bahwa tidak terdapat pengaruh yang signifikan antara keterlibatan kerja dengan variabel turnover intentions di PT Sumber Purnama Sakti Mataram

Secara terpisah ( parsial ) keterlibatan kerja tidak berpengaruh secara signifikan terhadap keinginan seorang karyawan untuk berhenti kerja. Seseorang karyawan bisa saja mempunyai keterlibatan kerja yang rendah namun hal itu tidak serta merta membuat seseorang akan keluar dari pekerjaannya karena faktor-faktor seperti pasar kerja, kesempatan kerja, alternatif dan usia merupakan hal yang penting untuk dipikirkan 
sebelum seorang akan meninggalkan pekerjaannya. Robbins (2003)

\section{Hasil Uji Parsial Variabel Komitmen Pada Organisasi}

Dari hasil perhitungan didapat hasil untuk varabel komitmen pada organisasi sebesar -5,596 dengan tingkat signifikansi sebesar 0,000 yang artinya terdapat pengaruh yang signifikan antara komitmen pada organisasi dengan turnover intentions di PT Sumber Purnama Sakti Mataram

Menurut Mobley (1979) pada Lum et al., (1998) komitmen organisasional diartikan yaitu adanya keinginan yang pasti untuk mempertahankan keikutsertaannya dalam organisasi. Individu yang rnemiliki komitmen organisasional rendah cenderung untuk mencari kesernpatan kerja yang lebih baik dan keluar dan pekerjaannya karena dalam diri mereka telah tertanam keinginan untuk keluar organisasi.

Beberapa penelitian seperti Lum et al., (1998); Lee et al.,(1992); Lee \& Mowday (1987) menyimpulkan bahwa Individu yang memenuhi komitmen organisasional akan memiliki tingkat kepuasan kerja yang tinggi dan intensi keluar yang semakin rendah.

Dari nilai t hitung dapat kita ketahui bahwa kepuasan kerja merupakan factor paling dominan yang paling berpengaruh terhadap niat seseorang untuk berhenti bekerja di PT Sunber Purnama Sakti Mataram yaitu sebesar $-6,054$ bila dibandingkan dengan keterlibatan kerja dan komitmen pada organisasi

Hal ini terjadi karena rata-rata usia karyawan PT Sumber Purnama Sakti adalah relatif dalam usia muda. Maier (1971) mengemukakan pekerja muda mempunyai tingkat turnover yang lebih tinggi daripada pekerja-pekerja yang lebih tua.

Penelitian-penelitian terdahulu menunjukkan adanya hubungan yang signifikan antara usia dan intensi turnover dengan arah hubungan negatif. Artinya semakin tinggi usia seseorang, semakin rendah intensi turnovernya (dalam Mobley,1986). Karyawan yang lebih muda lebih tinggi kemungkinan untuk keluar. Salah satu karakteristik pekerja dalam usia muda adalah mereka mempunyai pola konsumtif yang tinggi sehingga kepuasan merupakan faktor utama yang diinginkan oleh mereka Gilmer (1966). Jika mereka merasa puas dengan pekerjaannya maka faktor-faktor lain seperti keterlibatan kerja dan komitmen pada organisasi akan mengikuti

Adanya kepuasan kerja yang dirasakan akan memberikan pengaruh yang positif. Karyawan akan selalu termotivasi untuk selalu bersemangat sehingga kinerja akan meningkat. Dengan kata lain dapat disimpulkan bahwa sebelum seorang karyawan mempunyai tingkat keterlibatan kerja dan komitmen pada organisasi, maka yang menjadi ukuran pertama mereka adalah tingkat kepuasan kerja, karena didalam kepuasan kerja terdapat hal-hal yang menjadi tujuan utama seorang pekerja sehingga mereka mau bekerja seperti gaji, kesempatan untuk maju, pengakuan dan lain sebagainya. Jika apa yang menjadi harapan seorang karyawan bisa terpenuhi maka karyawan tersebut akan memiliki motivasi yang kuat untuk bekerja yang akan memberikan dampak pada keterlibatan kerja yang tinggi dan meningkatnya komitmen pada organisasi dan pada ahirnya menurunkan tingkat permintaan untuk berhenti kerja

\section{SIMPULAN}

Berdasarkan hasil analisis yang telah diuraikan pada bab IV, maka dapat ditarik kesimpulan sebagai berikut :

1. Kepuasan kerja, keterlibatan kerja dan komitmen pada organisasi karyawan PT Sumber Purnama Sakti Mataram secara rata-rata masih dalam katagori rendah.

2. Turnover intentions karyawan PT Sumber Purnama Sakti Mataram secara rata-rata dalam katagori tinggi

3. Berdasarkan hasil pengujian secara serempak dapat diketahui bahwa kepuasan kerja, keterlibatan kerja dan komitmen pada organisasi mempunyai pengaruh yang signifikan terhadap turnover intentions pada PT. Sumber Purnama Sakti..

4. Berdasarkan hasil pengujian secara parsial diperoleh hasil bahwa variabel Keterlibatan kerja ( X2 ) tidak memiliki 
pengaruh signifikan terhadap turnover intentions di PT Sumber Purnama Sakti.

5. Kepuasan kerja dan Komitmen pada organisasi memiliki pengaruh significant terhadap turnover intentions di PT Sumber Purnama Sakti

\section{SARAN}

Berdasarkan atas kesimpulan diatas, maka saran yang dapat diberikan adalah :

1. Bagi Perusahaan

PT. Sumber Purnama Sakti hendaknya memperhatikan tingkat kepuasan kerja karyawannya karena hal ini merupakan pengaruh paling dominan terhadap keinginan karyawan untuk berhenti, sehingga jika kepuasan kerja meningkat, maka diharapkan secara otomatis keterlibatan kerja dan komitmen pada organisasi pun akan dapat meningkat sehingga turnover intentions dalam perusahaan dapat berkurang.

2. Bagi Peneliti Selanjutnya

Mengingat bahwa penelitian ini menggunakan tiga variabel yaitu kepuasan kerja, keterlibatan kerja dan komitmen pada organisasi dan ketiga variable tersebut hanya mampu menjelaskan pengaruh turnover intentions hanya 61 persen,maka diharapkan penelitian berikutnya diharapkan mampu untuk menjelaskan variable-variabel lain yang mempengaruhi turnover intentions selain variable yang sudah digunakan dalam penelitian ini.

\section{DAFTAR PUSTAKA}

Andini, Rita, 2006, Analisis Pengaruh Kepuasan Gaji, Kepuasan Kerja, Komitmen Organisasional terhadap Turnover Intention: Studi Kasus Pada Rumah Sakit Roemani Muhammadiyah Semarang, Magister Management, Universitas Diponegoro Semarang.

Algifari. 2000 . Analisis Regresi Teori, Kasus, dan Solusi, edisi kedua. Yogyakarta : BPFE

Gozali, Imam. 2005. Aplikasi Analisis Multivariate Dengan Program SPSS. Semarang: Badan Penerbit Universitas Diponegoro Semarang.

Hersusdadikawati, Endang. 2005. Pengaruh Kepuasan atas Gaji Terhadap Keinginan Untuk Berpindah Kerja, Dengan
Komitmen Organisasional Sebagai Variabel Intervening (Studi empiris pada Dosen Akuntansii Perguruan Tinggi Swasta Jawa Tengah). Magister Management, Universitas Diponegoro Semarang.

Luthans, Fred, 2006, Perilaku Organisasi, Edisi kesepuluh, Penerbit Andi Offset.

Meyer, John, P., Allen, Natalie, J. \& Smith, Catherina A, 1993, Commitment to Organizational and Occupation : Extention and Test of a Three Component Conceptualization, Journal Applied Psychology, Vol. 78. No.4.

Mueller, John Dwight Kammeyer, 2003, Turnover Process in a Temporal Context :It's about Time, on line (www.emeraldinsight.com).

Meyer, John, P., Allen, Natalie, J. \& Smith, Catherina A, 1993, Commitment Organizational and Occupation : Extention and Test of a Three Component Conceptualization, Journal Applied Psychology, Vol. 78. No.4.

Porter, L.W., R. Steers, R. Mowdey, and P. Boulian, 1974, Organization Commitment, Job Satisfaction and Turnover among Psychiatric Tecniciants, Journal Applied Psychology, Vol. 59, October, pp.603609

Priyatno, Dwi . 2008. Mandiri Belajar SPSS. Jakarta: PT. Elex Media Komputindo

Robbins, Stephen P, 2001, Perilaku Organisasi, Edisi Kesepuluh, PT Indeks : Kelompok Gramedia.

Ruslan, Rosady. 2003. Metode Penelitian Public Relations dan Komunikasi. Jakarta : PT. Raja Grafindo Persada .

Suhanto, Edi, 2009, Pengaruh Stres kerja dan Iklim Organisasi Terhadap Turnover Intention Dengan kepuasan Kerja Sebagai Variabel Intervening (Studi di Bank Internasional Indonesia). Magister Management, Universitas Diponegoro Semarang.

Sugiyono. 2006. Metode Penelitian Bisnis. Bandung :Alfabeta. 
Santoso, Singgih. 2002. SPSS: Statistik Parametrik. Jakarta : PT Elex Media Komputindo

Shaw, Jason D, Delery, John E, Jenkins, G. Douglas Jr, and Gupta, Nina, 1998, An Organization-Level Analysis of Voluntary and Involuntary Turnover, Academy of Management Journal, Vol. 41, No.5, October, pp.511-525.

Werther, WB dan Davis, K, 1996, Human Resources and Personel Management, McGraw Hill Inc, New York.

Witasari, Lia. 2009. Pengaruh Kepuasan Kerja Dan Komitmen Organisasional Terhadap Turnover Intentions (Studi Empiris Pada Novotel Semarang). Magister Management, Universitas Diponegoro Semarang.

Zeffane, Rachid, 1994, Understanding Employee Turnover: The Need for a Contingency Approach, International Journal of Manpower, Vol. 15, No. 9, pp. 1-14. 